Acta vet. scand. $1986,27,479-485$.

From the Department of Dermatology, Södersjukhuset, Stockholm, Farmek, Visby, National Bacteriological Laboratory, Stockholm, and the National Veterinary Institute, Uppsala, Sweden.

\title{
ANTIBODIES TO BORRELIA SPIROCHETES IN SERA FROM SWEDISH CATTLE AND SHEEP
}

\author{
By \\ A. Hovmark, E. Asbrink, O. Schwan, B. Hederstedt \\ and D. Christensson
}

HOVMARK, A., E. ÅSBRINK, O. SCHWAN, B. HEDERSTEDT and D. CHRISTENSSON: Antibodies to Borrelia spirochetes in sera from Swedish cattle and sheep. Acta vet. scand. 1986, 27, 479-485. - In the southern parts of Sweden a Borrelia infection transmitted by the tick Ixodes ricinus may affect man. In the present study antibodies to Borrelia spirochetes were studied in sera from 58 cows, 68 calves and 13 lambs from areas in southern Sweden where Ixodes ricinus occurs. For comparison, serologic studies were also performed on 88 cows and 10 lambs from the northern parts of Sweden.

Serum titers of $>80$ were found in 14 of the calves and 23 of the cows from southern Sweden but in only 1 of the cows from northern Sweden. In 11 of the lambs from the south a serum titer of $>40$ developed. None of the lambs from the north had a serum titer of $>40$. The results indicate that cattle and sheep in certain areas of Sweden are exposed to Ixodes ricinus-borne Borrelia spirochetes.

In 9 of the lambs from southern Sweden an endemically occurring arthritis had developed. The possibility that this arthritis may be caused by Borrelia spirochetes is discussed.

Ixodes ricinus; arthritis.

Recently discovered Borrelia spirochetes, transmitted by Ixodes (I.) ticks, may cause infection in man.

In the United States the name Lyme disease has been coined for Ixodes-borne borreliosis, which may affect different organ systems (Steere et al. 1977). The name Borrelia burgdorferi has been given to the spirochetes involved (Johnson et al. 1984). This infection can be transmitted by I. dammini and I. pacificus (Burgdorfer et al. 1982, Johnson et al. 1984).

In the southern parts of Sweden and in many other European countries ticks of the species I. ricinus occur. This tick can trans- 
mit a spirochete, closely related to Borrelia burgdorferi, which in man may cause cutaneous manifestations (erythema chronicum migrans Afzelius, lymphadenosis benigna cutis, acrodermatitis chronica atrophicans), manifestations from the nervous system (meningitis, polyneuritis) and disorders of the joints (arthritis, subluxations) (Asbrink 1985, Stiernstedt 1985).

In the United States mice and deer are important reservoirs of Borrelia spirochetes (Bosler et al 1984b). Antibodies to Borrelia burgdorferi have also been found in New England horses (Marcus et al. 1985). Apart from studies in humans, there have hitherto been no investigations on mammalian hosts in Scandinavia.

The island of Gotland in the Baltic, in the southern part of Sweden, is an area where borreliosis occurs endemically in humans. During the summer months Gotlandic lambs may develop an arthritis of unknown etiology. Empirically penicillin has been found to cure this arthritis if given during the early phase of the disease, and the farmers have suspected that ticks play an etiologic role. To our knowledge this type of arthritis is unknown among lambs in northern Sweden.

Bovine babesiosis in Sweden is caused by Babesia divergens (Christensson, to be published), a protozoan also transmitted by I. ricinus. Especially in the south east parts of Sweden clinical cases are common during the grazing season (Wahlgren et al. 1984). The geographical distribution of Babesia divergens in Sweden (Olson 1961, Wahlgren et al. 1984) is reasonably the same as that of $\mathrm{I}$. ricinus.

The purpose of the present study was to determine whether cattle or sheep bred in areas of Sweden where I. ricinus occurs may develop a serologic response to Borrelia spirochetes.

\section{MATERIALS AND METHODS}

\section{Cattle}

Sera were collected from 3 different groups of cattle.

Group 1 consisted of sera from 88 cows from northern Sweden, which is beyond the limit of the natural distribution of I. ricinus. All animals had grazed during the summers, none had titers of antibodies to Babesia.

Group 2 consisted of 58 sera from cows bred in southern Sweden. As an indicator of contact with Ixodes ticks, only sera 
which in a previous analysis had shown elevated titers of antibodies to Babesia were included.

Group 3 consisted of sera from 68 calves from stocks in southern Sweden, stocks in which babesiosis was known to occur. Blood samples were collected just before and after the grazing season, which lasted for about 4.5 months. Before grazing all calves were seronegative for Babesia and after grazing there were 15 seropositive animals.

\section{Lambs}

Sera were collected from 13 lambs living on the island of Gotland in southern Sweden. Nine of these lambs suffered from arthritis, which was being treated with penicillin at the time of the first serum sampling (test 1). From these lambs a second serum sample was drawn 3 to 8 weeks later (test 2). During the same period of the autumn, when the second samples were drawn, sera were also collected from 10 lambs from Jämtland in the northern part of Sweden.

\section{Serologic tests}

The sera were stored at -20 or $-70^{\circ} \mathrm{C}$ until used in tests for assay of IgG antibodies to Borrelia spirochetes. A modification of the indirect immunofluorescence (IF) test described previously (Åsbrink et al. 1984) was employed and spirochetes isolated from a Swedish patient with tickborne borreliosis were used as antigen. The tests were performed with rabbit anti-bovine IgG, respectively rabbit anti-sheep IgG labeled with fluorescein isothiocyanate (Miles Laboratories). The serologic results are presented as reciprocal titers.

Sera from the cattle were also analyzed for antibodies to Babesia divergens with a modified IF-test (Christensen, to be published), where titers of 40 or more were considered as positive.

\section{Statistics}

The Wilcoxon rank-sum test was used in the statistical calculations.

Cattle

\section{RESULTS}

The results of the determinations of serum IgG antibodies to Borrelia spirochetes are presented in Tables 1 and 2. The sera 
T a b l e 1. Results of determinations of serum IgG antibodies to Borrelia in adult cows.

\begin{tabular}{|c|c|c|c|c|c|c|c|c|}
\hline & \multirow[b]{2}{*}{ No. } & \multicolumn{7}{|c|}{ Titer } \\
\hline & & $<20$ & 20 & 40 & 80 & 160 & 320 & $\geq 640$ \\
\hline $\begin{array}{l}\text { Cows from northern Sweden } \\
\text { (area free from I. ricinus) }\end{array}$ & 88 & 36 & 23 & 21 & 7 & 0 & 1 & 0 \\
\hline $\begin{array}{l}\text { Cows from southern Sweden } \\
\text { (area infested with I. ricinus) }\end{array}$ & 58 & 1 & 2 & 9 & 23 & 19 & 1 & 3 \\
\hline
\end{tabular}

from the group of Babesia-positive cows from southern Sweden showed a significantly higher median titer of antibodies to Borrelia spirochetes than sera from cows from northern Sweden $(\mathrm{P}<0.001)$. A serum titer of $>80$ was found in 23 of the 58 Babesia-positive cows from the south, but in only 1 of the 88 cows from the north (Table 1).

At the end of the summer 14 of the 68 calves had developed titers of antibodies against Borrelia spirochetes higher than 80 (Table 2). There was no significant difference in serum titers of antibodies to Borrelia spirochetes between the $\mathbf{1 5}$ calves, which after grazing were positive for Babesia, and those which remained Babesia-negative.

T a b l e 2. Results of determinations of serum IgG antibodies to Borrelia in calves before and after grazing on pasture where I. ricinus occur.

\begin{tabular}{lrrrrrrrr}
\hline & & \multicolumn{1}{c}{ Titer } \\
\cline { 3 - 10 } & No. & $<20$ & 20 & 40 & 80 & 160 & 320 & $\geq 640$ \\
\hline Calves before grazing & 68 & 16 & 18 & 23 & 10 & 1 & 0 & 0 \\
Calves after grazing & 68 & 7 & 11 & 17 & 19 & 11 & 3 & 0 \\
\hline
\end{tabular}

\section{Lambs}

The results of the determinations of serum IgG antibodies to Borrelia spirochetes in lambs are shown in Table 3. In paired sera from the Gotlandic lambs the titers increased significantly by two titer steps or more in 7 of the 13 cases and increasing titers were found both among lambs with and without arthritis. In 11 of the 13 lambs from Gotland a serum titer or 80 or higher developed, but all lambs from Jämtland in northern Sweden displayed serum titers less than 80 . 
T a b l e 3. Results of determinations of serum IgG antibodies to Borrelia in lambs.

\begin{tabular}{lccccccccc}
\hline & & \multicolumn{1}{c}{ Titer } \\
\cline { 3 - 9 } & No. & $<\mathbf{1 0}$ & $\mathbf{1 0}$ & $\mathbf{2 0}$ & $\mathbf{4 0}$ & $\mathbf{8 0}$ & $\mathbf{1 6 0}$ & 320 \\
\hline Lambs from Gotland, test 1 & 13 & 0 & 0 & 4 & 4 & 5 & 0 & 0 \\
Lambs from Jämtland & 13 & 0 & 0 & 0 & 2 & 4 & 5 & 2 \\
test 2 & 10 & 2 & 6 & 1 & 1 & 0 & 0 & 0 \\
\hline
\end{tabular}

\section{DISCUSSION}

The results of this study indicate that cattle and sheep in certain areas of Sweden are exposed to I. ricinus-borne Borrelia spirochetes. Leptospira organisms may cause cross-reacting antibodies. However, this spirochetal infection has only very rarely been demonstrated in Swedish ruminants (Hurvell, pers. comm.). All calves investigated came from stocks in which babesiosis was known to occur and it is likely that all calves in these areas run a risk of being parasitized by ticks. Among the calves increasing serum titers of antibodies to Borrelia spirochetes developed irrespective of whether or not serologic positivity to Babesia developed. Thus, the results do not suggest that ticks harbouring the Babesia protozoa bear Borrelia spirochetes more often than other I. ricinus ticks.

The question whether a Borrelia spirochete infection in ruminants may result in clinical symptoms, or just gives a subclinical infection, is still not answered. In man Ixodes-borne borreliosis may cause arthritis (Burgdorfer et al. 1982, Åsbrink 1985, Stiernstedt 1985). Clinical findings indicate that arthritis may also develop in dogs infected with tick-borne Borrelia spirochetes (Bosler et al. 1984a). In this investigation elevated titers of antibodies to Borrelia spirochetes were found both in Gotlandic lambs with and in those without arthritis. These results may be explained by the occurrence of both clinical and subclinical infections. However, the hypothesis that Ixodes-borne spirochetes may cause endemically occurring arthritis in lambs needs further investigation, including attempts to isolate spirochetes from affected animals. It is also important that the agent responsible for the seroresponse of the ruminants is identified, as ruminants may serve as reservoirs for the spirochetes causing borreliosis in humans. 


\section{ACKNOWLEDGEMENTS}

We thank Elisabeth Ishizaki for skilful technical assistance. This work was supported by grants from the Welander foundation and from the Swedish Medical Research Council (grant 7935).

\section{REFERENCES}

Bosler, E. M., H. Camay, B. G. Ormiston \& J. L. Benach: Spirocheteassociated arthritis (Lyme disease) in a dog. J. Amer. vet. med. Assoc. 1984, 185, 219-222.

Bosler, E. M., B. G. Ormiston, J. L. Coleman, J. P. Hanrahan \& J. L. Benach: Prevalence of the Lyme disease spirochete in populations of white-tailed deer and white-footed mice. Yale J. Biol. Med. 1984, 57, 651-659.

Burgdorfer, W., A. G. Barbour, S. F. Hayes, J. L. Benach, E. Grunwaldt \& J. P. Davis: Lyme disease - a tick-borne spirochetosis? Science 1982, 216, 1317-1319.

Johnson, R. C., G. P. Schmid, F. W. Hyde, A. G. Steigerwalt \& D. J. Brenner: Borrelia burgdorferi sp nov.: Etiologic Agent of Lyme Disease. Int. J. Bact 1984, 34, 496-497.

Marcus, L. C., M. M. Patterson, R. E. Gilfillan \& P. H. Urband: Antibodies to Borrelia burgdorferi in New England horses: Serologic survey. Amer. J. vet. Res. 1985, 46, 2570—2571.

Olson, H.: Studien über das Auftreten und die Verbreitung der Rinderleukose in Schweden. (Studies on the occurrence and distribution of bovine leukosis in Sweden). Acta vet. scand. 1961, Suppl. 2, 22-46,

Steere, A. C., S. E. Malawista, J. A. Hardin, S. Ruddy, P. W. Askenase \& W. A. Andiman: Erythema chronicum migrans and Lyme arthritis. The enlarging clinical spectrum. Ann. Intern. Med. 1977, 86, 685-698.

Stiernstedt, G.: Tick-borne Borrelia infection in Sweden. Scand. J. infect. Dis. 1985, Suppl. 45, $1-63$.

Wahlgren, M., D. Christensson, R. Bergqvist, A. Björkman, P. O. Pehrsson \& L. Rombo: Babesios, en risksjukdom för immundefekta i Sverige. (Babesiosis in Sweden, a disease which may effect patients with immunodeficiency). Opusc. Medica 1984, 29, 2628.

Åsbrink, E.: Erythema chronicum migrans Afzelius and acrodermatitis chronica atrophicans. Early and late manifestations of Ixodes ricinus-borne Borrelia spirochetes. Acta Derm. Venereol. (Stockh.) 1985, Suppl. 118, 1-63.

Äsbrink, E., A. Hovmark \& B. Hederstedt: The spirochetal etiology of acrodermatitis chronica atrophicans Herxheimer. Acta Derm. Venereol (Stockh.) 1984, 64, 506-512. 


\section{SAMMANFATTNING}

Serum antikroppar mot Borreliaspiroketer hos nötkreatur och får i Sverige.

Det har nyligen visats att Borrelia spiroketer som överförs av Ixodes ricinus fästingar orsakar infektion hos människa. Denna borrelios förekommer endemiskt i södra och mellersta delarna av Sverige. 58 kor, 68 kalvar och 13 lamm från södra Sverige och 88 kor och 10 lamm från norra Sverige har undersökts med avseende på förekomsten av serum antikroppar mot Borrelia spiroketer. Serum titrar $>80$ påvisades hos 14 av kalvarna och 23 av korna från södra Sverige men endast hos en av korna från norra Sverige. 11 av lammen från södra Sverige erhöll efter betessäsongen en serum titer $>40$. Inget av de nordsvenska lammen hade serum titer $>40$. Resultaten tyder på att nötkreatur och får i vissa områden av Sverige är exponerade för Ixodes ricinus överförda spiroketer.

Nio av de undersökta lammen från södra Sverige hade drabbats av en endemiskt förekommande artrit. Hypotesen att denna artrit orsakas av Borrelia spiroketer diskuteras.

(Received June 24, 1986).

Reprints may be requested from: A. Hovmark, the Department of Dermatology, Södersjukhuset, S-100 64 Stockholm, Sweden. 